\title{
Stress Relaxation of Ionomers of \\ Styrene/Methacrylic Acid Copolymer
}

\author{
Kenkichi Murakami \\ Chemical Research Institute of Non-aqueous \\ Solutions, Tohoku University*
}

\begin{abstract}
Stress relaxation curves were obtained for ionomers containing different cations and with different percents of ionization. Based polymer used here was a copolymer of styrene and methacrylic acid (85/15). The rate of stress relaxation was in the order of $\mathrm{Na}^{+}$-ionomer, based polymer and $\mathrm{Zn}^{2+}$-ionomer.

The stress relaxation behavior of these polymers showed as if they were crystalline polymers. A model recently proposed for ionomers was discussed and found to have been consistent with these results. By the application of W.L.F. equation for these polymers, it was found that these were two different terms of stress relaxation mechanism among the polymer molecules. The primary and secondary transitions observed in solid polymers have generally been interpreted in terms of concept of "molecular motions". On the other hand, R.D. Andrews has proposed that these transition are explained in terms of the thermal breakdown of different types of intermolecular secondary bonding in the solid state. Stress relaxation mechanism in this study was well explained by R.D. Andrews's definition for polymer transition.
\end{abstract}

* 2-1-1, Katahira, Sendai-shi 


\section{スチレン〜メタクリル酸共重合体 \\ アイオノマーの応用緩和}

村上謙吉*

要 旨

スチレンとメタクリル酸の共重合物（モノマー比 85/15）をべースポリマーとして $\mathrm{Na}^{+}$, $\mathrm{Zn}^{2+}$ イオンのアイオノマーの弾性率の緩和挙動を単純延伸により検討した。いずれの試 料に関してもそれが無定形ポリマーであるにもかかわらず，結晶性ポリマーのよらな緩和 挙動を示した。そしてWLF 式との適合性の検討から二つの異なる分子緩和機構が存在す ることがわかった。また，転移温度は Andrews (1) $^{1}$ とより定義された分子間の二次結合が

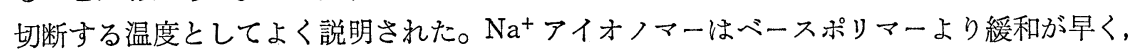
$\mathrm{Zn}^{2+}$ アイオノマーは遅いといら結果を得た。この現象も分子間水素結合の量和よびイオ ン橋カケと関係づけられることがわかった。

1. 分子構造の化学的変化の分類

一般に橋カケ高分子の分子構造に関して, これを化学変化的に分類すると, 次の 3 項目 となる。

a）主鎖分子切断反応

橋カケ高分子に招いて，主鎖分子のみが切断する場合，相対応力を $f(t) / f(0)$, 活性定 数を $k_{1}$ とすると, 次式で示される2。

$$
\frac{f(t)}{f(0)} \approx e^{-k_{1} t}
$$

b ) 橋カケ点切断反応

橋カケ高分子に颃いて, 橋カケ点のみ切断する場合, 同じく相対応力を $f(t) / f(0)$, 活 性定数を $k_{2}$ とすると, 次式の関係が成り立つ。

$$
\frac{f(t)}{f(0)} \approx e^{-k_{2} t}
$$

この場合は，a)の近似的 Maxwell 曲線ではなく， 正確な Maxwell 曲線を描くことを示 している。

c）交換切断反応

この場合は一次結合では, 主価結合の例としては, ポリサルファイド結合, シリコーン ポリマー結合の例がある。下式のようである。

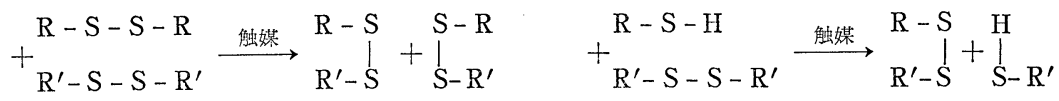

$$
\begin{aligned}
& +\underset{\mathrm{R}^{\prime}-\mathrm{S}-\mathrm{S}-\mathrm{R}^{\prime}}{\mathrm{R}-\mathrm{S}-\mathrm{Na}} \longrightarrow \begin{array}{l}
\mathrm{R}-\mathrm{S} \mathrm{Na} \\
\mathrm{I}+\mathrm{R}_{\mathrm{R}}^{\prime} \mathrm{S}-\mathrm{R}^{\prime}
\end{array} \quad+\begin{array}{l}
\mathrm{R}-\mathrm{S}-\mathrm{Pb}-\mathrm{S}-\mathrm{R} \\
\mathrm{R}^{\prime}-\mathrm{S}-\mathrm{S}-\mathrm{R}^{\prime}
\end{array} \longrightarrow \begin{array}{c}
\mathrm{R}-\mathrm{S}-\mathrm{Pb} \mathrm{S}-\mathrm{R} \\
\mathrm{R}^{\prime}-\mathrm{S}
\end{array}
\end{aligned}
$$

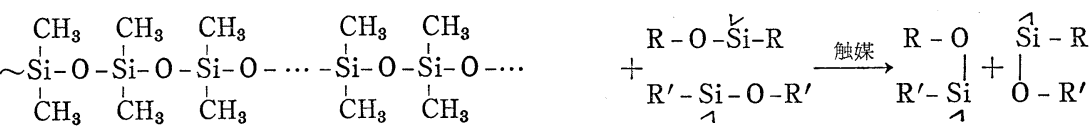

昭和 47.6.28 受理 * 東北大学非水溶液化学研究所 仙台市片平 $2-1-1$ 
一方，一次結合の中でイオン結合の例とし ては，右戝のような場合がある。

近傍の鎖との強い相互作用点, たと光ば水 素結合や塩結合のようなものを生じうるょう ないくつかの官能基をもつ高分子に物いて

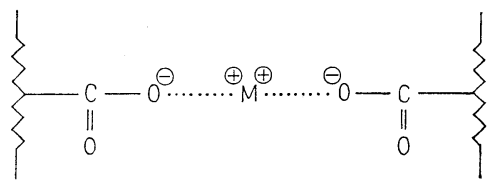
は，切断特よび再生を行なう一時的な “物理的” 橋カケが高分子鎖間に形成されると考兄 られる。

アイオノマーの橋カケ結合の実体は，上記の c) 交換反応に基づくもの，拈よび物理的 橋カケに基づくものと考光られる。

この場合の定量的関係は下式のようである ${ }^{3)}$ 。

$$
\frac{f(t)}{f(0)}=A e^{-k_{3} t}+B e^{-k_{4} t}
$$

\section{1. 緒}

\section{言}

アイオノマーは未橋カケの熱可塑性ポリマーの長所と 一般の化学的橋カケポリマーの長所をかね年ななたポリ マーとして興味深い。つまり未橋カケポリマーは熱可塑 性はあるが物性上の欠点があり，また橋カケポリマーは 逆に機械的性質はすぐれているが流動性，すなわち加工 性がない。この両者の長所を生かしたのが金属イオンで 橋カケしたアイオノマーであり，ここ数年来注目を浴び 合成と物性の両面から多くの研究がなされてきた

本研究ではアイオノマーの粘弾性的特性を検討するた めに単純延伸法を用いて緩和弾性率を測定した。ポリマ 一はスチレン/メタクリル酸共重合体をベースポリマー として選び，金属イオンは一価として $\mathrm{Na}^{+}$イオン，二 価として $\mathrm{Zn}^{2+}$ イオンを用いた。そしてアイオノマーの 分子構造と粘弾性挙動を結びっけて検討した。

\section{2. 実験}

\section{1 試料}

ベースポリマーはモノマーとしてスチレンとメタクリ ル酸, 乳化剂にェマルダン $147\left(\mathrm{R}-\mathrm{O}-\left(\mathrm{C}_{2} \mathrm{H}_{4} \mathrm{O}\right)_{n} \mathrm{H}\right.$, 花王 アトラス社製)と、レベノール $\left(\mathrm{R}-\phi-O-\left(\mathrm{C}_{2} \mathrm{H}_{4} \mathrm{O}\right)_{n} \mathrm{SO}_{3} \mathrm{Na}\right.$, 花王アトラス社製)，触媒に過硫酸カリウム，連鎖移動 剤にラウリルメルカプタン，そして水はイオン交換水を 用いて通常の乳化重合を行なって得た共重合体である。 そのモノマー比は 85/15である。また，そのアイオノマ 一はベースポリマーの $\mathrm{pH}$ をアンモニア水で $5 \sim 6$ 亿調 整後, 酶酸西鉛若しくは酶酸ナトリウムの水溶液を添加 し，常温にて 30 分かきまぜ，反応させる。反応終了後 のポリマーはメタノールにて凝析し, 水一タノール混 合液で抽出後乾燥する。このようにして得たポリマーの 特性を表-1 に示した。

\section{2 実験装置および方法}

Table 1. Basic characterizations of the samples studied

\begin{tabular}{c|c|c|c|c|c}
\hline Sample & $\begin{array}{c}\text { St/MAA } \\
{[\mathrm{wt} \%]}\end{array}$ & $\eta_{\mathrm{sp}}^{\mathrm{a})}$ & $\begin{array}{c}\text { Melt flow } \\
\text { rateb) } \\
(\mathrm{g} / 10 \mathrm{~min})\end{array}$ & $\begin{array}{c}\text { Ion and } \\
\text { concen- } \\
\text { tration } \\
\text { (wt } \%)\end{array}$ & “ $T_{g}$ ” \\
\hline $\mathrm{SM}$ & $85 / 15$ & 0.405 & 73.5 & 0 & $125^{\circ} \mathrm{C}$ \\
$\mathrm{SMZ-1}$ & $85 / 15$ & 0.50 & 0.6 & $\mathrm{Zn}^{2+}=2.1$ & $130^{\circ} \mathrm{C}$ \\
$\mathrm{SMZ-2}$ & $85 / 15$ & & 0.1 & $\mathrm{Zn}^{2+}=2.6$ & $132^{\circ} \mathrm{C}$ \\
$\mathrm{SMN}$ & $85 / 15$ & & 28.4 & $\mathrm{Na}^{2+}=0.48$ & $120^{\circ} \mathrm{C}$ \\
\hline
\end{tabular}

a) $C=0.50 \mathrm{~g} / 100 \mathrm{~m} l$ of $\mathrm{DMF}$, at $25^{\circ} \mathrm{C}$

b) At $230^{\circ} \mathrm{C}$ and $30.6 \mathrm{~kg} / \mathrm{cm}^{2}$

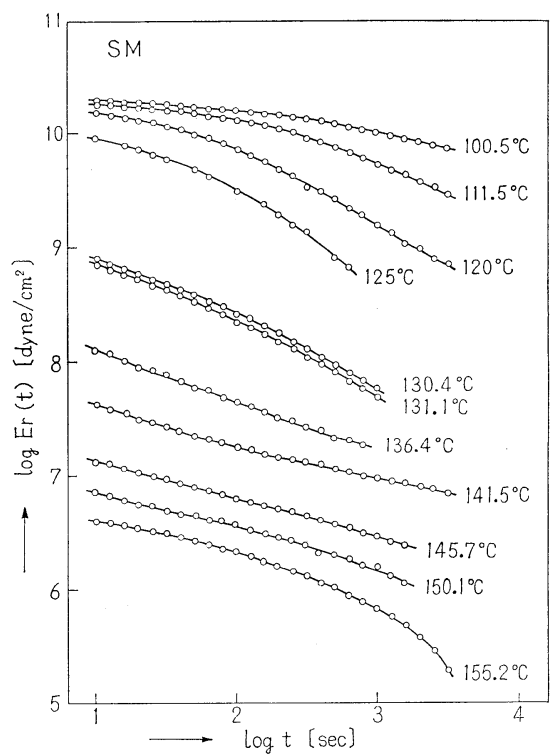

Fig. 1. Stress relaxation of styrene/methacrylic acid copolymer, sample SM

応力緩和実験に用いた装置は当研究室草野, 村上 ${ }^{8)}$ に より作製されたもので，ストレインゲージを用いてい る。測定は緩和弾性率 $E_{r}(t)=10^{10} \sim 10^{9} \mathrm{dyn} / \mathrm{cm}^{2}$ まで を $5 \sim 2 \mathrm{~kg}$ のロードセル， $E_{r}(t)=10^{9} \sim 10^{8} \mathrm{dyn} / \mathrm{cm}^{2}$ を 


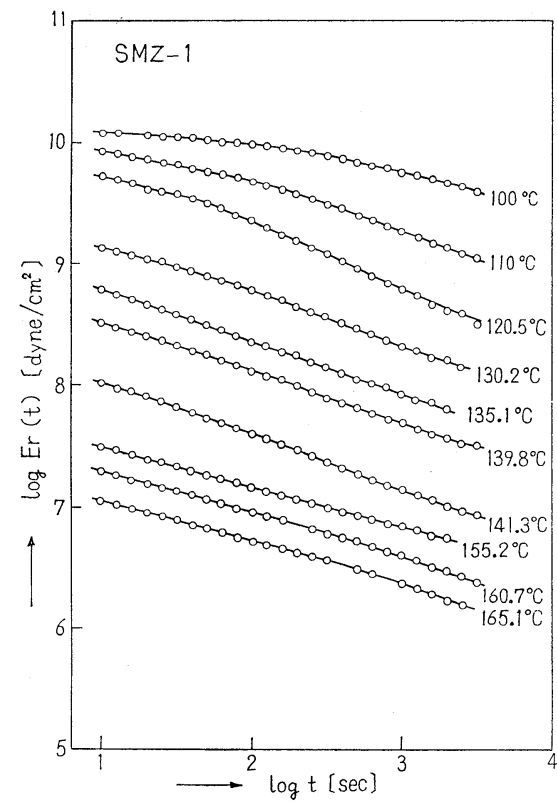

Fig. 2. Stress relaxation of zink-linked ionomer, sample SMZ-1

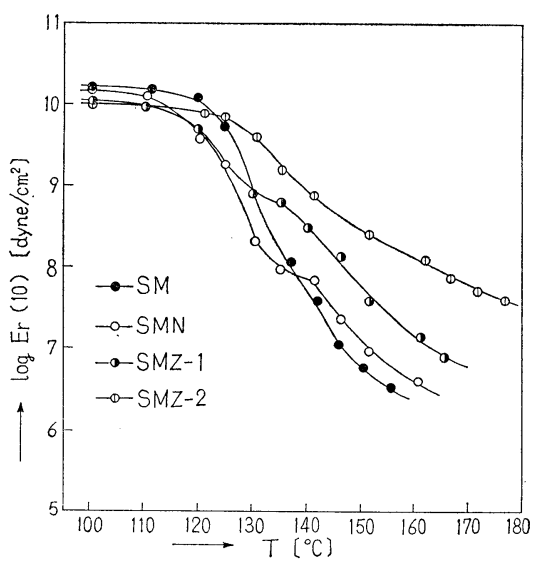

Fig. 3. Modulus-temperature behavior for four polymers

$400 \mathrm{~g}$ のロードセル，それ以下の $E_{r}(t)$ については 100 $\mathrm{g}$ のロードセルを用い，0.3〜 $5 \%$ の伸長ヒズミを瞬間 に与えてのち, 約 30 分間応力の変化を追跡した。恒温 槽の精度は $\pm 0.1^{\circ} \mathrm{C}$ である。

すべての測定試料は $180^{\circ} \mathrm{C}$ で 30 分間 $200 \mathrm{~kg} / \mathrm{cm}^{2}$ でプ レス，十分アニールしたのち $5 \times 1 \times 0.1 \mathrm{~cm}$ の 大ささに テストピースとして採取した。

\section{3. 結果および考察}

図-1 特よび図-2 は SM と SMZ-1 に関する各温度に

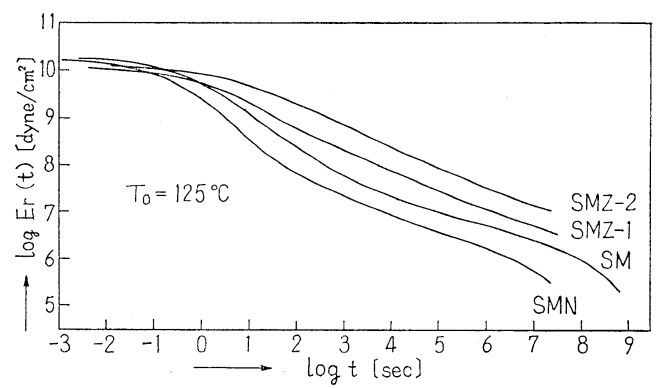

Fig. 4. Basic curves of four polymers

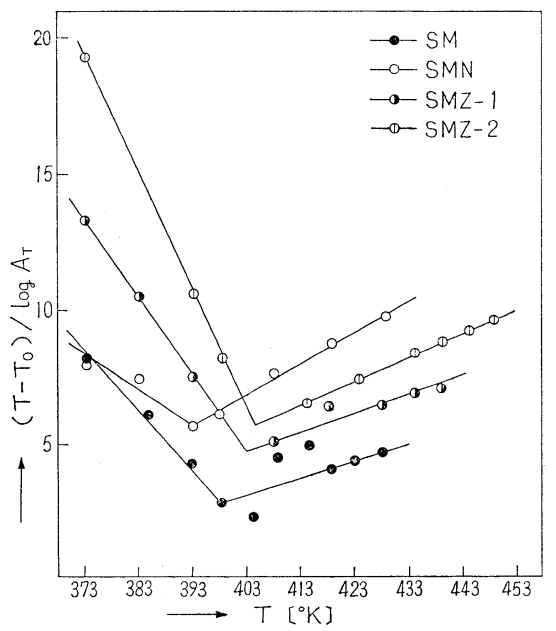

Fig. 5. Relation between $\left(T-T_{0}\right) / \log A_{r}$ and $T$

特ける緩和弾性率 $\log E_{r}(t)$ と時間 $\log t$ の関係である*。 また，図-3 には緩和弾性率の 10 秒值 $\log E_{r}(10)$ と温 度 $T\left({ }^{\circ} \mathrm{K}\right)$ の関係を示した。これらの結果からわかるよ らに，一般の無定形ポリマーの緩和挙動に現われるガラ ス状領域, 転移領域, ゴム状領域, 流動領域のはっきり した区分がなく, あたかも結晶性ポリマーのような挙動 を示す。

一般の無定形ポリマーの場合には温度変化により分子 運動がミクロブラウン運動からマクロブラウン運動に転 じる温度すなわちガラス転移点 $T_{g}$ があり, その $T_{g}$ の 前後数度以内で $E_{r}(10)$ が $10^{10} \mathrm{dyn} / \mathrm{cm}^{2}$ (ガラス状) か ら $10^{7} \mathrm{dyn} / \mathrm{cm}^{2}$ (ゴム状) まで急激に変化する。しかし 図-3 はいずれの場合にもそのような変化はなく，温度 上昇につれて徐々に变化していくことがわかる。この変 化は丁度結晶性ポリマーの変化に対応している。また， 図-1〜2 から時間温度換算則の成立を仮定して得た合成 曲線が図-4 である。基準温度として $125^{\circ} \mathrm{C}$ をとった。

* SMZ-2 や SMN について子類似した結果を得てい る。

$\overline{[12] \quad 11}$ 
この図-4 から結晶性ポリマーの挙動に類似しているこ とがさらに明確となる。いままでアイオノマーの物性研 究に用いられたものはエチレン/メタクリル酸共重合体 のような結晶部分を含むアイオノマー、モデル的に 3 成

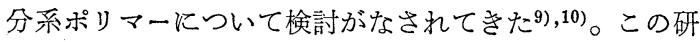
究に用いた試料はそれぞれのモノマーの構造からみてま た，X線回折からも回折像は現われないので無定形ポリ マーと考光られる。

そこで, この実験事実からしてこのポツマー（アシド ポリマー）について分子構造上から検討する必要がある ように思劣る。まずわれわれは，転移について検討し た。図-5は合成曲線作成に際して得た移動因子 $a_{T}$ の温 度依存性が，はたしてWLF 式の関数式で与えられるか 否かをチェックした結果である。若し WLF 式が成立す るとすれば, WLF 式を変形した式 (1) からわかるよら に, $\left(T-T_{0}\right) / \log a_{T}$ と $T$ の関係は，一つの直線を与え るはずである。図 -5 から明らかのように，いずれの場 合にもこの関係は成立せず特定の温度で屈折する 2 直線 で表わされることがわかる。この屈折点を表-1 に示し た。

$$
\left(T-T_{0}\right) / \log a_{T}=-\left(C_{2}^{\circ} / C_{1}^{\circ}\right)-\left(T-T_{0}\right) / C_{1}^{\circ}
$$

以前 K. Fujino, K. Senshu, H. Kawai ら ${ }^{11), 12)}$ は,

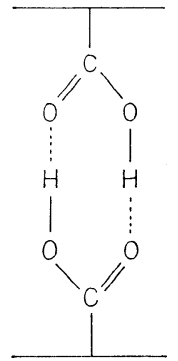
ポリビニルアルコールの部分特よび 高度ホルマール化によって，低結晶 性より凝結晶性あるいは無定形へ順 次構造の変化した一連のポリビニル ホルマールについて上記のわれわれ と同じ取り扱いを行ないWLF 式の 関係を得るかどらかを検討した。無 定形物に関しては，一つの直線で表 わされるが, 結晶化の高いるの汪ど

Fig. 6. Structure はっきりした折線を与えることを示 of acid copolymer

した。その理由として彼らは試料が 無定形から結晶性に変化するにつ

れ，無定形のゴム領域に対応する鎖間の機械的からみ合 いのほどけを伴うような単純な分子間緩和機構が微結晶 の結晶構造のゆるみ，あるいは異常に強い分子間二次結 合の解離を伴うような異種の分子間緩和機構に変化す ることによると説明している。われわれの得た結果と H. Kawai らの結晶性ポリマーに関する結果とは種々の 点で類似していることがわかる。H. Kawai らの結果と の対比から，この研究に用いた共重合物に二つの緩和機 構が予想される。ただ大さな相違はわれわれの用いたポ リマーが無定形であることである。そこでこのポリマー の分子構造を検討してみる。W. J. Mcknight ${ }^{13)}$ 物よび
T. Kajiyama ら ${ }^{\mathbf{1 4})}$ はエチレン/メタクリル酸のようなア シッド共重合体の構造は図-6 のように表わされること を報告した。つまり $-\mathrm{COOH}$ 基が分子間で水素結合を形 成し，それが丁度橋カケの上らな構造を有している。こ の分子構造和よび結晶性ポリマーとの類似性を考慮に入 れて,つぎのよらにこのポリマーの弾性率の緩和挙動を 考察した。ベースポリマーに特いては $125^{\circ} \mathrm{C} て ゙$ 転移が生 じる。この場合の“転移”とは一般の無定形ポリマーの転 移点 $\left(T_{g}\right)$ の概念とは異なる。すなわち従来の $T_{g}$ が分子 運動に関係づけられる項として説明されてきたが R. D. Andrews ${ }^{1)}$ は他の定義として分子間の二次結合が熱的 に切断を受ける点として “ $T_{g}$ ”を説明した。この R.D. Andrews の “ $T_{g}$ ”をこのポリマーに適用すると前述の 緩和挙動や図-7 に郝けるWLF 式からのズレを説明す ることができる。H. Kawai らの結果と同様にして, 125 ${ }^{\circ} \mathrm{C}$ を基点として低温側と高温側の二つの緩和挙動が存 在する。低温領域の直線性は一般の無定形ポリマーの緩 和挙動で説明される。つまり $125^{\circ} \mathrm{C}$ までは図-6 の分子 間水素結合が安定であるので，ここに現われる緩和現象 は側鎖などのミクロブラウン運動によるものと考えられ る $125^{\circ} \mathrm{C}$ (R.D. Andrews の定義する “Tg”) に物いて 分子間水素結合が切断を受ける。この切断は $125^{\circ} \mathrm{C}$ 以上 では温度が上昇するにつれて増加する。これは丁度結晶 ポリマーに括ける微結晶部分の消失と対比される。した がって無定形ポリマーであるにもかかわらず結晶ポリマ 一に類似した弾性率緩和曲線を与兄るものと思われる。 このことは下記の実験結果からより一層明確にされる。 K. Ogura，K.Sobue ${ }^{15)}$ は，ここに用いたのと同じべー スポリマー $(\mathrm{SM})$ の赤外線吸収スペクトルの熱変化を追 跡, 研究した。彼らによれば, 低温側から $125^{\circ} \mathrm{C}$ を゙ monomeric carbonyl group 执よび分子間二次結合と考 えられる dimerized carbonyl group の吸収量の変化は 全くないが, $125^{\circ} \mathrm{C}$ を境に温度の増加に伴い monomeric carbonyl groupの吸收が増大するのに反して dimerized carbonyl group の吸収が減少することを認めた。そし て $125^{\circ} \mathrm{C}$ そ. D. Andrews 定義の “ $T_{g}$ ” と結論してい る。またこの両者の吸収量の大きさのあいだには温度に よる可逆性が成り立ち，一度高温まで上げたものを逆に 下げていくと monomeric carbonyl group の量が減少 し, dimerized carbonyl group が増大する。そして $125^{\circ} \mathrm{C}$ 以下では両者が一定となると述べている。このこ とは前述のわれわれの考皇を支持する。

つぎに Tobolsky7) はアイオノマーの粘弾性的研究を した。そのなかで金属イオンの種類濃度の影響を検討 し，緩和弾性率は金属イオンの種類によらず，金属イオ 
ン濃度によって影響を受け，それが大きくなるにつれ緩 和速度は小さくなると述べている。しかしわれわれの得 た結果によれば, 図-4 に示すように $\mathrm{Na}^{+}$のアイオノマ 一はベースポリマーの緩和よりも早い。SMZ に関して は緩和は遅くなり，緩和弾性率も大きい。このことから 緩和速度は金属イオンに影響されて, 一価イオンと二価 イオンのあいだに相違があることがわかる。また表-1 に示したように, “ $T_{g}$ もとれぞれ異なった値をとる。

図-4 に関して分子構造上から考察してみると，一価 イオン拉よび二価イオンアイオノマーの相違はつぎのよ らになる。一価イオンである SMN の場合には分子間水 素結合が切断を受けて $-\mathrm{COO}^{-} \mathrm{Na}^{+}$となる。すなわち, ベースポリマーに比較して分子間の二次結合（弱い橋カ ケ）が減少する。他方二価イオンである SMZ の場合に は - $\left(\mathrm{COO}^{-}\right) \mathrm{Zn}^{2+}(-\mathrm{OOC})-$ のように分子間二次結合が消 失する反面, 強いイオン結合による橋カケが形成され る。このように分子構造を考学ていくと図-4 に現われ た現象は容易に説明される。まず SMN が SM よりも緩 和が早くなるのは分子間水素結合の消失によるものであ ると考光られる。また， SMZ が SM より緩和が遅く， それが $\mathrm{Zn}^{2+}$ イオン量に比例していることは, 形成され たイオン橋カケ結合の安定のためであるとい方る。井 手, 長浴川に占によれば, このように形成されたイオン結 合は $250^{\circ} \mathrm{C}$ ぐらいまで安定であるといわれる。以上の考 察からは図-3 に括汀る $\log E_{r}(10)$ と $T$ の関係に括い て, SM と SMZ が逆転するところを説明しえない。こ れはつぎのように考觉る。単純に分子構造上の問題とし て取り扱ってきたが，金属イオンの性質を考虑に入れな かった。Tobolsky7) とよれば，金属イオンの含む領域 は他のポリマーのみの領域と比較して “hard region”
だといわれる。したがって SMN と SM の図-3 の逆転は 金属イオンの含さ，“hard region”によると解釈され る。

$$
\text { 文献 }
$$

1) R. D. Andrews : J. Polymer Sci., Part C. 14, 261 (1966)

2) A. V.Tobolsky, D. J. Metz, R. B. Mesrobiarn : J.A.C.S., 72, 1942 (1950)

3) A. V. Tobolsky : Polymer Letters, 2, 823(1964) R. B. Beevers: J. Colliod Sci., 19, 40 (1964)

4) B. A. Dolgoplask, E. I. Tinyakva : Rubber Chem. \& Tech., 32, 321 (1959)

5）井手文雄，長谷川章：高化，25，825（1968）

6) E. E. Magat, I. K. Miller : J. Polymer Sci., C 4, 615 (1963)

7) N. D. Zakharov, Rubber Chem. \& Tech., 36, 568 (1969)

8）草野孝衛, 村上謙吉 : 東北大学非水溶液化学研究 所研究報告, 20, 199 (1970)

9) T. C. Ward, A. V. Tobolsky : J. Appl. Polym. Sci., 11, 2403 (1967)

10) L. E. Nielsen, W. E. Fitzgerald : Proc. Roy. Soc. (London), A 282, 137 (1962)

11) K. Fujino, K. Senshu, T. Horino, H. Kawai : J. Colloid Sci., 17, 726 (1962)

12) K. Fujino, K. Senshu, T. Horino, H. Kawai : Ibid., 18, 119 (1963)

13) W. J. Mcknight, L. M. Mckemna, B.E. Read, R.S. Stein : J.Phys.Chem., 73, 1122 (1968)

14) T. Kajiyama, R. S. Stein, W. J. Mcknight: Abstracts, SPST 19 th Symposium on Macromolecules, Kyoto, Oct. 20 (1970)

15) K. Ogura, K. Sobue, Polymer Journal, 3, 155 (1972)

報文

\section{色材助会䜡 Vo1.46, No.1(予告)}

長期防污性の研究（第 3 報）主鎖分裂型高分子害物駆除剤の長期防污性に及ぼす影響

酸化重合によるリグノスルホン酸塩の不溶化

テーマ資料（三次元化と空気酸化による網状化）

総論：三次元化ポリマー

最近の橋力ケ酸化形塗料用樹脂

橋力ケ硬化塗膜の物性

空気酸化による塗膜の網状化

特許公告

文桶

色材サロン

関西ペイント(怢) ‘赤金華津男他

関西ペイント姝）赤金華津男他

横浜国大 垣 内弘

日清製油侏 長 倉 稔

三菱電機㑣）柴山恭一他

武蔵工大 高 岡 京 